\title{
Immunolocalization of Transforming Growth Factor- $\alpha$, Epidermal Growth Factor (EGF), and EGF-Receptor in Normal and Injured Developing Human Lung
}

\author{
THOMAS P. STRANDJORD, JOAN G. CLARK, DANIEL E. GURALNICK, AND \\ DAVID K. MADTES \\ Departments of Pediatrics and Medicine, University of Washington, and Fred Hutchinson Cancer \\ Research Center, Seattle, Washington 98195
}

\begin{abstract}
ABS
The family of growth factors that includes epidermal growth
factor (EGF) and transforming growth factor- $\alpha$ (TGF- $\alpha$ ) are
thought to play a role in the regulation of fetal lung development
and epithelial repair after injury. To further elucidate the poten-
tial role of these growth factors and their receptor in normal
human lung development and in response to injury, their distri-
bution was determined by immunohistochemistry in normal fetal
lung, as well as both normal and injured postnatal human lung.
We studied 14 specimens of human lung tissue: from three
fetuses, four normal infants, two preterm infants with hyaline
membrane disease, and five infants with late bronchopulmonary
dysplasia (BPD). EGF, TGF- $\alpha$, and EGF receptor (EGF-R)
colocalized in airway epithelium in normal fetal and in postnatal
human lung. They were also colocalized in scattered alveolar
epithelial cells in postnatal lung. Large numbers of alveolar
macrophages immunostained for EGF, TGF- $\alpha$, and EGF-R in
\end{abstract}
lungs with late stages of BPD. The colocalization of these growth factors suggests parallel expression of EGF family members. Moreover, the colocalization of these growth factors with their receptor in developing lung suggests that they may act through an autocrine mechanism. The prominent expression of these growth factors in alveolar macrophages in BPD suggests they may be involved with the pathogenesis of this disease. (Pediatr Res 38: 851-856, 1995)
Abbreviations
BPD, bronchopulmonary dysplasia
EGF, epidermal growth factor
EGF-R, epidermal growth factor receptor
HMD, hyaline membrane disease
TGF- $\alpha$, transforming growth factor- $\alpha$

EGF and TGF- $\alpha$ are members of a family of proteins, the EGF family, which act through binding the $\operatorname{EGF-R~}(1,2)$. Human TGF- $\alpha$ and EGF share $42 \%$ sequence homology $(3,4)$ and have similar biologic activities in vitro. They are capable of stimulating proliferation of epithelial cells, endothelial cells, smooth muscle cells, and fibroblasts (5). Members of the EGF family have also been shown to be potent stimulants of the migration of many cell types, including keratinocytes, liver epithelial cells, enterocytes, corneal cells, and endothelial cells $(6-10)$. These properties have led to the speculation that members of the EGF family may be involved in the regulation of developmental processes.

Received March 10, 1995; accepted July 5, 1995

Correspondence and reprint requests: Thomas P. Strandjord, M.D., Department of Pediatrics, Mailstop RD-20, University of Washington, Seattle, WA 98195.

Supported by National Institutes of Health Grant HL-30542 (J.G.C.), an American Lung Association of Washington Research Grant (D.K.M.), a National Institutes of Health Clinical Investigator Award HL-02460 (D.K.M.). T.P.S. is a Parker B. Francis Fellow in Pulmonary Research.
Indeed, there is considerable evidence that members of the EGF family play a significant role in both normal lung development and response to injury. EGF-R have been identified in fetal mouse and rabbit lung and on rat type II pneumocytes (11-13). EGF immunoreactivity has been localized in epithelial cells, mesenchymal cells, and extracellular matrix of fetal mouse lung at $11 \mathrm{~d}$ of gestation (14). EGF has been shown, by immunohistochemistry, to be present in normal human fetal tracheal and bronchial submucosal glands and airway epithelial cells (15), but not in bronchiolar or alveolar cells. TGF- $\alpha$ mRNA has been isolated from human fetal lung during the pseudoglandular and canalicular stages. TGF- $\alpha$ immunoreactivity has been localized predominantly in epithelial cells, but it was also present in vascular smooth muscle and scattered mesenchymal cells (16). TGF- $\alpha$ mRNA has been isolated from late gestation rat lung $(17,18)$. EGF and TGF- $\alpha$ immunoreactivity have been colocalized with EGF-R in fetal rat lung epithelial cells (19). 
Stimulation of EGF-R activity in developing lung has been shown to promote growth and differentiation. Goldin and Opperman (20) demonstrated that agarose beads containing EGF can stimulate the formation of supernumerary tracheal buds from chick embryo foregut in much the same manner as the grafting of mesodermal tissue. Warburton et al. (14) have shown that treatment of fetal mouse lung organ explants with exogenous EGF stimulates branching morphogenesis and cellular proliferation and that specific inhibition of EGF-R function inhibits branching morphogenesis and cellular proliferation (14). Also, inhibition of endogenous EGF production with an antisense oligonucleotide directed against EGF in fetal mouse lung explants reduced airway branching (21). Pharmacologic treatment of fetal rat, monkey, rabbit, and sheep lungs at various gestational ages with EGF results in accelerated type II cell differentiation, DNA synthesis, and surfactant production $(22-25)$.

There is also evidence that the EGF family may play a role in the response of lung to injury. Fibroblasts isolated from lungs of hamsters exposed to hyperoxia secreted TGF- $\alpha$, whereas fibroblasts from normal lungs did not (26). In a rat model of lung injury, lungs exposed to bleomycin had increased steady state levels of TGF- $\alpha$ and EGF-R mRNA, increased TGF- $\alpha$ protein content, and increased EGF-R (27). These findings suggest that the local release of TGF- $\alpha$ may influence the lung's response to injury.

To better understand the role of EGF family growth factors in normal human lung development we have immunolocalized EGF, TGF- $\alpha$, and EGF-R in developing human fetal and infant lung. We have also studied the distribution of EGF, TGF- $\alpha$, and EGF-R in injured lung from infants with HMD and BPD as a first step in analyzing the role of these growth factors in the response of infant lung to injury.

\section{METHODS}

Tissue specimens. This study was approved by the Institutional Review Committee of the University Washington School of Medicine. Fetal lung tissue samples from three therapeutically aborted fetuses at 11, 17, and 20 wk of gestation (obstetrical dates used throughout, computed by adding 2 wk to postconceptional age) with no known congenital abnormalities were collected by the Central Laboratory for Human Embryology of the University of Washington. Gestational age was estimated by foot length (28). All tissue was fixed in $10 \%$ buffered formalin within $30 \mathrm{~min}$ of abortion.

Normal infant lung tissue samples from four infants at 3,6, 9, and 12 mo of age were obtained from the King County Medical Examiners Office, Seattle, WA. The 3-mo-old infant was diagnosed with sudden infant death syndrome. All other infants expired in motor vehicle accidents. None of these infants had any known pulmonary abnormalities. All tissue was fixed in $10 \%$ buffered formalin.

Lung tissue samples from two infants with severe early HMD and five infants with BPD were obtained from the pathology service of the University of Washington Medical Center, Seattle, WA. The infants diagnosed with severe early HMD were 24 and 25 wk of gestation with birth weights 568 and $750 \mathrm{~g}$, respectively, and died in the $1 \mathrm{st} \mathrm{d}$ of life. The diagnosis of HMD was based on a clinical course and chest roentgenograms consistent with the disease, as well as typical pathologic changes, which included the presence of hyaline membranes and widespread atelectasis. The infants diagnosed with BPD were 23.5-31 wk of gestation, with birth weights ranging 680-1453 g, and died of respiratory failure at 34-151 $\mathrm{d}$ of age. The diagnosis of BPD was based on a clinical course and chest roentgenograms consistent with the disease (29), as well as typical pathologic changes, which included extensive fibrosis and alternating areas of atelectasis and emphysema. All tissue was fixed in $10 \%$ buffered formalin.

Antibodies. An affinity-purified mouse monoclonal $\operatorname{IgG}_{2 \mathrm{a}, \mathrm{k}}$ antibody to human recombinant TGF- $\alpha$ (Oncogene Science, Manhasset, NY) was used to detect TGF- $\alpha(16,30,31)$. It recognizes an epitope within the carboxyl-terminal 17-amino acid residues of TGF- $\alpha$ (residues 34-50) and does not cross-react with EGF. EGF-R was detected using an affinity-purified rabbit polyclonal IgG antibody (Oncogene Science) raised against the peptide (DVVDADEYLIPQ) that corresponds to amino acid residues 1005-1016 of the cytoplasmic domain of the human EGF-R (32). This antibody specifically reacts with the $170-\mathrm{kD}$ EGF-R protein by immunoblot analysis (manufacturer's specifications). An affinity-purified rabbit polyclonal $\mathrm{IgG}$ antibody to human recombinant EGF (Oncogene Science) was used to detect EGF. Epithelial cells were specifically stained with a mouse monoclonal antihuman cytokeratin, clones AE1 and AE3 (Boehringer Mannheim, Indianapolis, IN) (33). HAM-56, a mouse MAb specific for macrophages (Dako Corporation, Carpinteria, CA), was used to identify alveolar macrophages (34).

Immunohistochemistry. Sections of lung $5 \mu \mathrm{m}$ thick were stained with the ABC peroxidase method as previously described $(16,35)$. The sections were counterstained with methyl green. Sections immunostained with anti-cytokeratin or HAM-56 antibodies were enhanced with nickel chloride and counterstained with acridine orange (36). Color photomicrographs were produced using a Jenaval photomicroscope and Kodak Ektachrome 64T transparency film. The slides were scanned and digitized on a Kodak Photo CD. The digitized images were then processed using Adobe PhotoShop for Windows 2.5 software (Adobe Systems Inc., Mountain View,

Table 1. Characteristics of study patients

\begin{tabular}{ccccc}
\hline Case & Gest age (wk) & Birth weight $(\mathrm{g})$ & Postnatal age & Diagnosis* \\
\hline 1 & 11 & - & - & Fetal \\
2 & 17 & - & - & Fetal \\
3 & 20 & - & - & Fetal \\
4 & term & - & $3 \mathrm{mo}$ & SIDS \\
5 & term & - & $6 \mathrm{mo}$ & MVA \\
6 & term & - & $9 \mathrm{mo}$ & MVA \\
7 & term & - & $12 \mathrm{mo}$ & MVA \\
8 & 24 & 568 & $1 \mathrm{~d}$ & HMD \\
9 & 25 & 750 & $1 \mathrm{~d}$ & HMD \\
10 & 23.5 & 680 & $34 \mathrm{~d}$ & BPD \\
11 & 26 & 797 & $37 \mathrm{~d}$ & BPD \\
12 & 28 & 1453 & $122 \mathrm{~d}$ & BPD \\
13 & 29 & 1422 & $151 \mathrm{~d}$ & BPD \\
14 & 31 & 1104 & $105 \mathrm{~d}$ & BPD \\
\hline
\end{tabular}

* SIDS, sudden infant death syndrome; MVA, motor vehicle accident. 
CA) with identical parameters for all micrographs in each figure and were printed on a Phaser II SDX dye sublimation printer (Tektronix, Beaverton, OR).

As a control for specificity of the TGF- $\alpha$, EGF, and EGF-R antibodies, a 10-fold excess, by weight, of either human recombinant TGF- $\alpha$ (Life Technologies, Inc., Gaithersburg, MD), human recombinant EGF (Life Technologies), or the synthetic EGF-R peptide (DVVDADEYLIPQ, used to generate the EGF-R antibody) was used to preabsorb each of the antibodies at room temperature for $1 \mathrm{~h}$. These preabsorbed antibody preparations were used to stain serial fetal lung tissue sections, as described above.

\section{RESULTS}

Normal lung. Serial tissue sections from fetal human lungs at 11,17 , and $20 \mathrm{wk}$ of gestation, as well as from normal postnatal lungs from infants $3,6,9$, and 12 mo of age (Table 1) were immunostained for TGF- $\alpha$, EGF, and EGF-R (Fig. 1). TGF- $\alpha$, EGF, and EGF-R were colocalized in lungs at all ages studied (Table 2). The two growth factors and their receptor were uniformly present in bronchial epithelium and submucosal glands, as well as in bronchiolar epithelium. Staining for TGF- $\alpha$, EGF, and EGF-R was observed in alveolar epithelium and in vascular smooth muscle in normal postnatal lung. Scattered alveolar macrophages also were immunopositive for TGF- $\alpha$, EGF, and EGF-R.
Lung with HMD and BPD. Serial tissue sections from lungs of premature infants, 23.5-31 wk of gestation, who died with HMD, at $1 \mathrm{~d}$ of age, and BPD, at 34-151 d of age (Table 1), were immunostained for TGF- $\alpha$, EGF, and EGF-R, as well as for markers for alveolar macrophages and epithelial cells (Figs. 2 and 3). As in normal lung, TGF- $\alpha$, EGF, and EGF-R expression were colocalized (Table 3). The two growth factors and their receptor were uniformly present in bronchial epithelium and submucosal glands, as well as in bronchiolar epithelium, throughout development and in spite of disease state. Staining for TGF- $\alpha$, EGF, and EGF-R was also observed in alveolar epithelium and in vascular smooth muscle in older infants with BPD.

In contrast to normal lungs, alveolar macrophages were abundant in lungs of infants with BPD, as demonstrated by immunostaining with HAM56 antibody (Fig. 3d). Serial sections were also immunostained for TGF- $\alpha$, EGF, and EGF-R (Fig. 3 and Table 2). Staining of intraalveolar macrophages with each of the antibodies in these sections suggested colocalization of these factors and their receptor in these cells. Intraalveolar macrophages were consistently immunostained for TGF- $\alpha$, EGF, and EGF-R in all fields.

Specificity of immunohistochemistry. Specificity of the EGF, TGF- $\alpha$, and EGF-R antibodies was confirmed by staining serial sections of fetal lung tissue with each antibody, or each antibody preabsorbed with a 10 -fold excess of human recombinant TGF- $\alpha$,

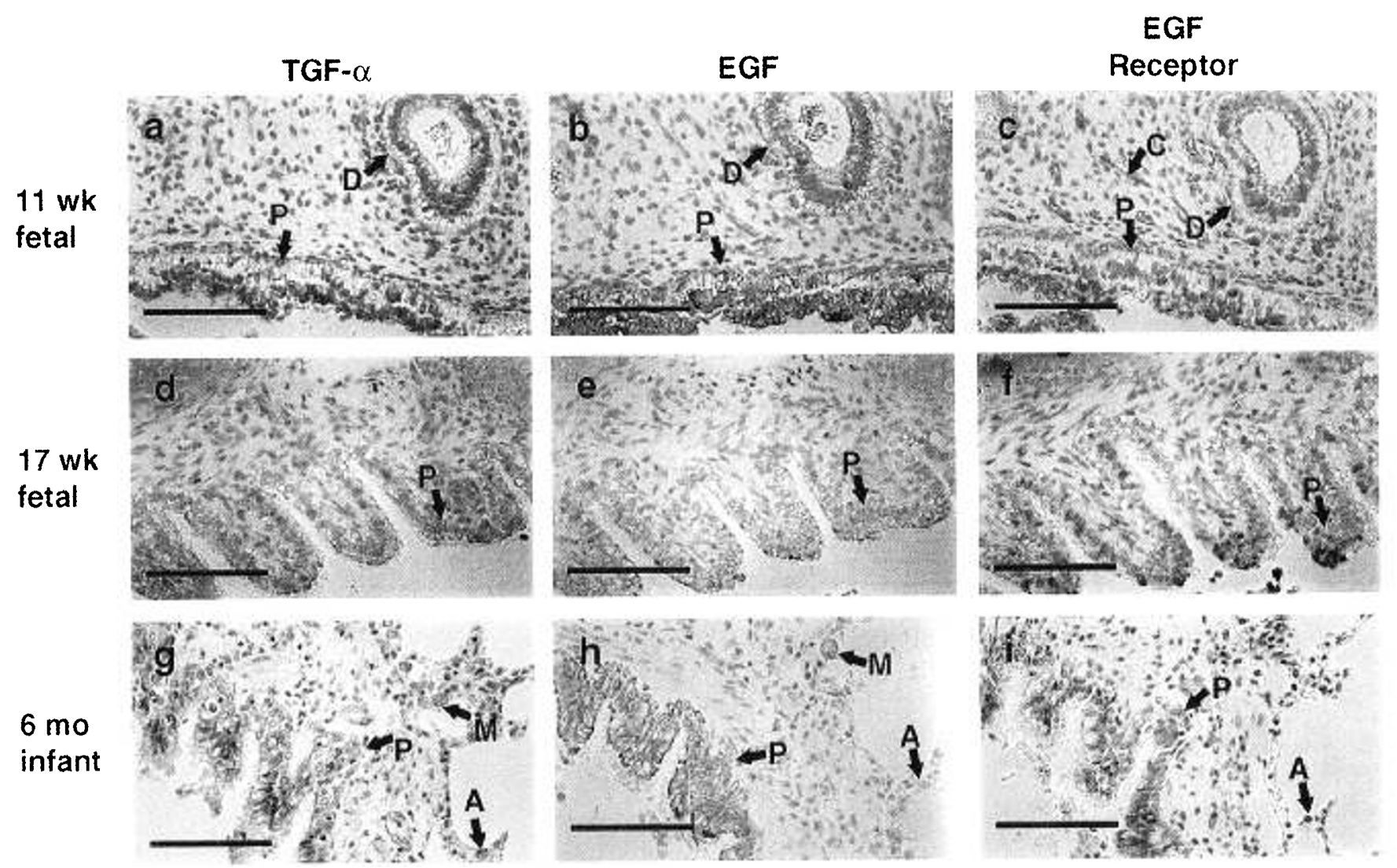

Figure 1. Distribution of TGF- $\alpha, \mathrm{EGF}$, and EGF-R immunoreactivity in normal developing human lung. Serial sections of normal human fetal lungs at 11 ( $a-c$ ) and $17(d-f)$ wk of gestation, and a 6-mo infant $(g-i)$ lung were immunostained with anti-TGF- $\alpha(a, d$, and $g)$, anti-EGF $(b, e$, and $h)$, and anti-EGF-R $(c, f$, and $i)$ antibodies. Examples of immunoreactive cells are marked as follows: distal epithelium, $D$; proximal epithelium, $P$; alveolar epithelium, $A$; capillaries, $C$; macrophages, $M$. (Counterstained with methyl green, bars $=100 \mu \mathrm{m}$.) 
Table 2. Summary of immunohistochemistry results in normal lung*

\begin{tabular}{|c|c|c|c|c|c|c|c|c|c|c|c|c|}
\hline \multirow[b]{2}{*}{ Case } & \multicolumn{3}{|c|}{ Bronchial epithelium } & \multicolumn{3}{|c|}{ Broncholar epithelium } & \multicolumn{3}{|c|}{ Alveoli/Saccules } & \multicolumn{3}{|c|}{ Vascular smooth muscle } \\
\hline & EGF & TGF- $\alpha$ & EGF-R & EGF & TGF- $\alpha$ & EGF-R & EGF & TGF- $\alpha$ & EGF-R & EGF & TGF- $\alpha$ & EGF-R \\
\hline 1 & N/A & N/A & N/A & + & + & + & + & + & + & + & + & + \\
\hline 2 & N/A & N/A & N/A & + & + & + & + & + & + & + & + & + \\
\hline 3 & + & + & + & + & + & + & + & + & + & + & + & + \\
\hline 4 & N/A & N/A & N/A & + & + & + & \pm & \pm & \pm & \pm & + & \pm \\
\hline 5 & N/A & N/A & N/A & + & + & + & \pm & \pm & \pm & + & + & \pm \\
\hline 6 & + & + & + & + & + & + & \pm & \pm & \pm & + & + & \pm \\
\hline 7 & + & + & + & + & + & + & \pm & \pm & \pm & + & \pm & \pm \\
\hline
\end{tabular}

$*+=$ present, $-=$ absent, $\pm=$ occasionally present, N/A $=$ structures not available in section, $0=$ structures not present.
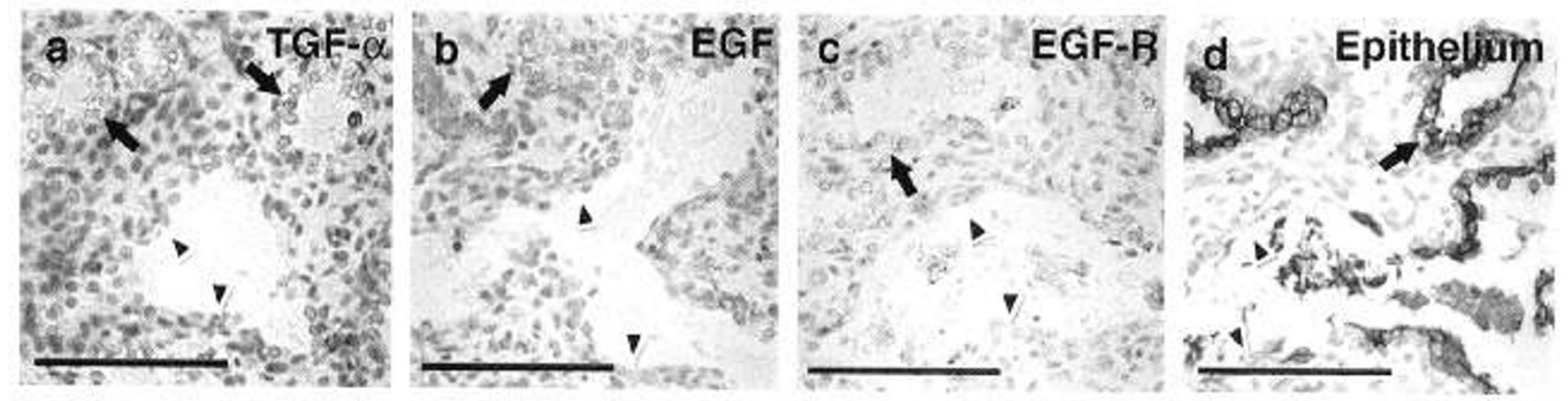

Figure 2. Distribution of TGF- $\alpha$, EGF, and EGF-K immunoreactivity in infant lung injured with HMD. Serial sections of lung from a 24-wk gestation, 10-d-old infant with HMD were immunostained with anti-TGF- $\alpha(a)$, anti-EGF $(b)$, anti-EGF-R $(c)$, and anti-cytokeratin (specific for epithelial cells) $(d)$ antibodies. Arrows point to examples of immunopositive epithelial cells and arrowheads mark areas of denuded basement membrane. $($ Bars $=100 \mu \mathrm{m}$.)

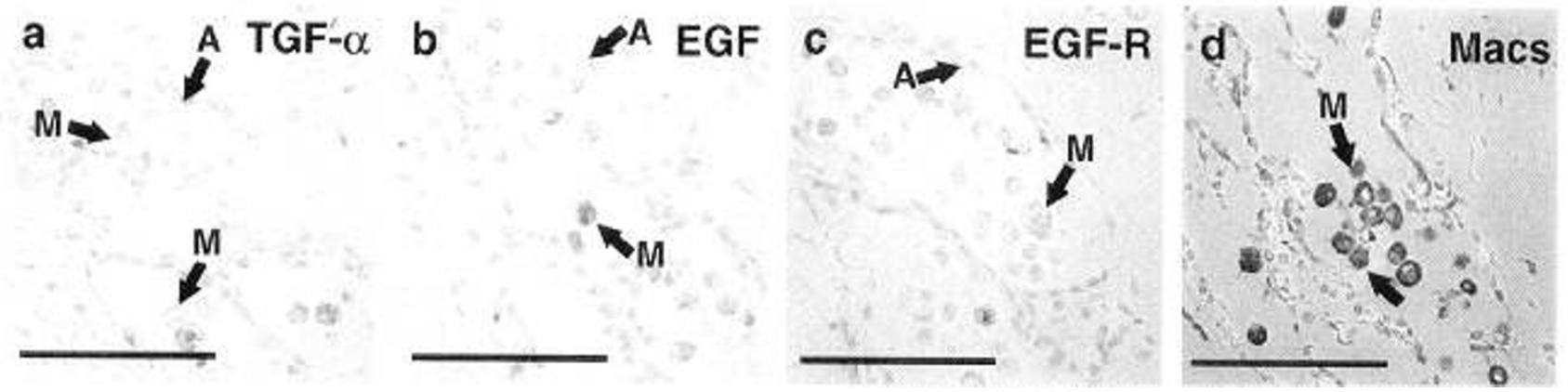

Figure 3. Distribution of TGF- $\alpha$, EGF, and EGF-R immunoreactivity in infant lung injured with BPD. Serial sections of lung from a 29-wk gestation, 150-d-old infant with BPD were immunostained with anti-TGF- $\alpha(a)$, anti-EGF $(b)$, anti-EGF-R $(c)$, and HAM 56 (specific for macrophages, Macs) $(d)$ antibodies. Examples of immunoreactive cells are marked as follows: alveolar epithelium, $A$; macrophages, $M$. (Bars $=100 \mu \mathrm{m}$.)

Table 3. Summary of immunohistochemistry results in injured lung*

\begin{tabular}{|c|c|c|c|c|c|c|c|c|c|c|c|c|c|c|c|}
\hline \multirow[b]{2}{*}{ Case } & \multicolumn{3}{|c|}{ Bronchial epithelium } & \multicolumn{3}{|c|}{ Broncholar epithelium } & \multicolumn{3}{|c|}{ Alveoli/Saccules } & \multicolumn{3}{|c|}{ Vascular smooth muscle } & \multicolumn{3}{|c|}{ Macrophages } \\
\hline & EGF & TGF- $\alpha$ & EGF-R & EGF & TGF- $\alpha$ & EGF-R & EGF & TGF- $\alpha$ & EGF-R & EGF & TGF- $\alpha$ & EGF-R & EGF & TGF- $\alpha$ & EGF-R \\
\hline 8 & + & + & + & + & + & + & + & + & + & + & + & + & 0 & 0 & 0 \\
\hline 9 & N/A & N/A & N/A & + & + & + & + & + & + & + & + & + & 0 & 0 & 0 \\
\hline 10 & + & + & + & + & + & + & + & + & + & + & + & \pm & + & + & + \\
\hline 11 & + & + & + & + & + & + & + & \pm & \pm & + & + & \pm & + & + & + \\
\hline 12 & + & + & + & + & + & + & + & \pm & \pm & \pm & + & + & + & + & + \\
\hline 13 & + & + & + & + & + & + & \pm & + & \pm & \pm & \pm & \pm & + & + & + \\
\hline 14 & + & + & + & + & + & + & + & \pm & + & + & + & \pm & + & + & + \\
\hline
\end{tabular}

$*+=$ present,$-=$ absent, $\pm=$ occasionally present, $\mathrm{N} / \mathrm{A}=$ structures not available in section, $0=$ structures not present.

human recombinant EGF, or the synthetic EGF-R peptide (Fig. 4). Immunoreactivity was not detected in the sections stained with each antibody preabsorbed with its respective antigen, indicating that each antibody reacted with its soluble antigen. Also, the sections incubated with antibodies preabsorbed with the other antigens were similar in the intensity and distribution of immunostaining compared with the sections stained with the antibody alone. This indicated that there was no cross-reactivity of these antibodies with the other antigens studied.

\section{DISCUSSION}

We have demonstrated that TGF- $\alpha$, EGF, and the EGF-R are colocalized in fetal lung from midgestation and in infant lung 


\section{Not Preabsorbed}

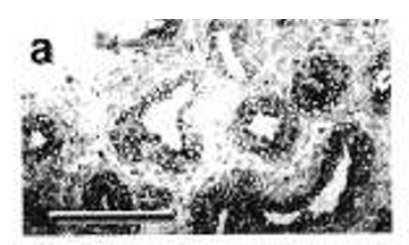

anti-EGF

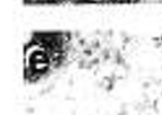

anti-TGF- $\alpha$

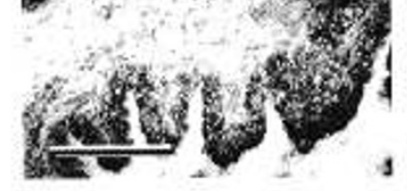

\section{Preabsorbed with TGF- $\alpha$}

\section{Preabsorbed with EGF}
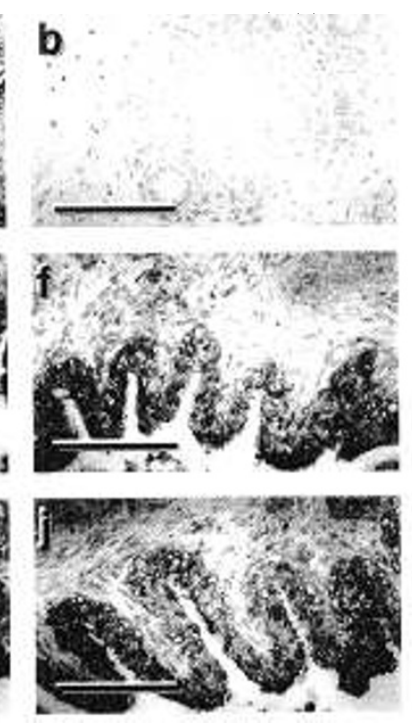
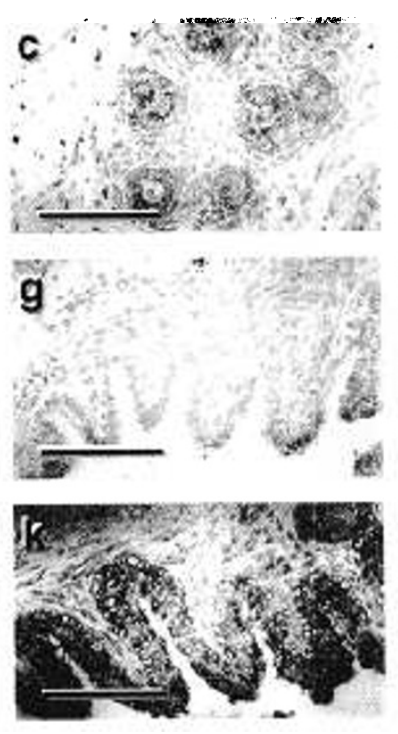

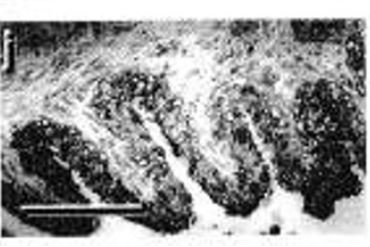

\section{Preabsorbed with EGF-R}

anti-EGF-R
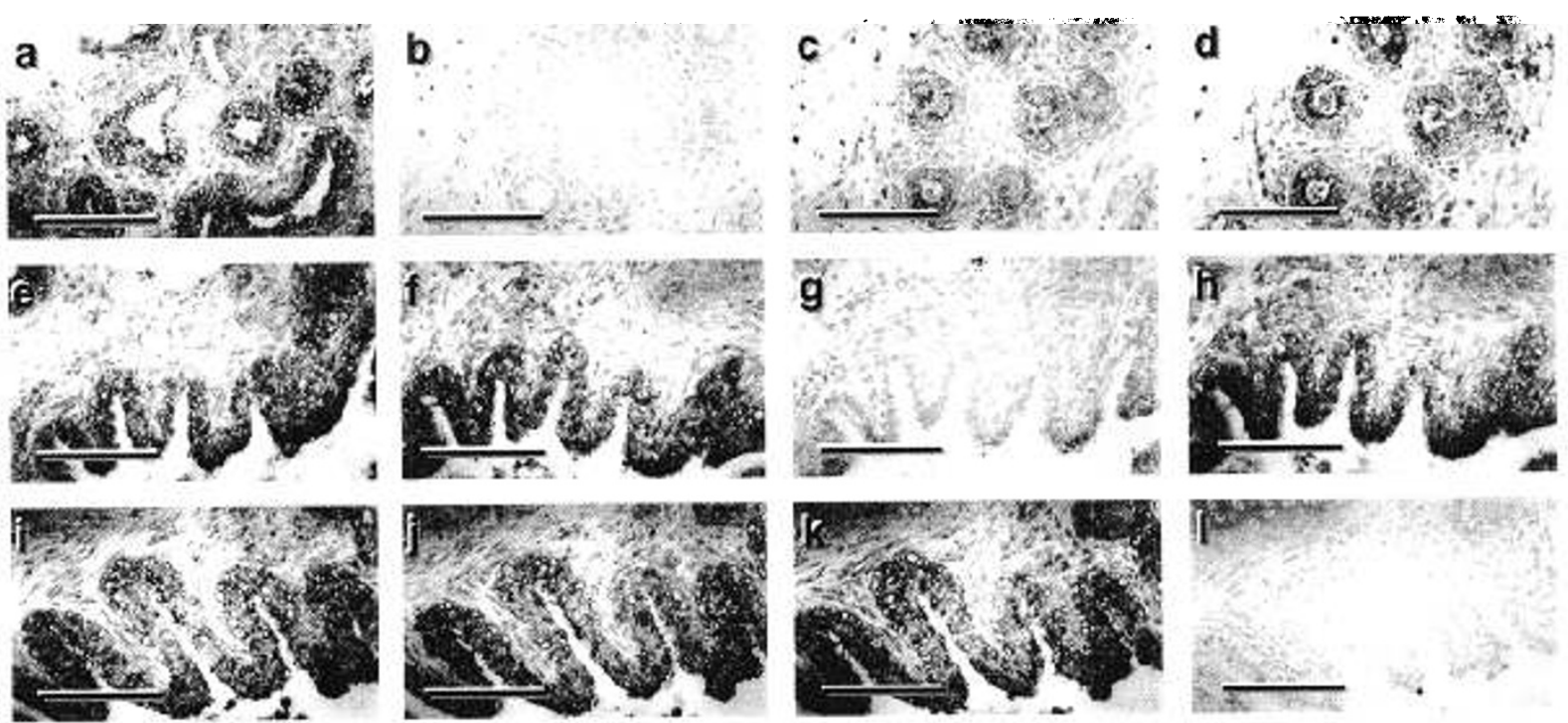

Figure 4. Specificity of immunostaining. Serial sections of a 17-wk gestation human fetal lung were immunostained with antibodies to TGF- $\alpha$ ( $a-d$ ), EGF $(e-h)$, or EGF-R $(i-l)$. Each of these antibodies was preabsorbed with a 10 -fold excess of either: human recombinant TGF- $\alpha(b, f$, and $j)$, EGF $(c, g$, and $k$ ), or synthetic EGF-R peptide $(d, h$, and $l)$. (Bars $=100 \mu \mathrm{m}$.)

up to $1 \mathrm{y}$ of age. These growth factors and their receptor were consistently present in bronchial epithelium and submucosal glands, as well as in bronchiolar epithelium in both normal and injured developing lung. In postnatal infants they were present in alveolar epithelium with variable intensity of immunostaining. EGF, TGF- $\alpha$, and EGF-R were also present in fetal pulmonary vascular smooth muscle, but immunoreactivity was relatively less pronounced in postnatal infants. These results are consistent with descriptions of the distribution of TGF- $\alpha$ in fetal human and rat lung previously reported by our laboratory $(16,19)$, as well as the localization of EGF and EGF-R in developing mouse and rat lung $(13,14,19,37-39)$. EGF-R has been described in fetal rat (19) and mouse lung airways (14) and in adult rat type II alveolar epithelial cells in primary culture (13). Normal fetal and infant human lung EGF (15) and EGF-R (40) have been previously identified in tracheal and bronchial epithelium as well as submucosal glands. In contrast we detected EGF and its receptor in lung epithelium at all levels. It is possible that the discrepancy between those reports and our own observations could be explained by differences in the antibodies used. The colocalization of TGF- $\alpha$, EGF, and EGF-R in airway epithelium supports the hypothesis that EGF and TGF- $\alpha$ function in an autocrine manner to modulate epithelial cell function as has previously been suggested for EGF (13).

The identification of these growth factors and their receptor in human fetal and infant airways implicates these growth factors in regulation of human lung development. Their prominent localization in airway epithelium suggests a possible role in airway growth and epithelial cell differentiation and maturation. Many studies of pharmacologic treatment of developing lung with EGF have demonstrated potent effects on branching morphogenesis $(14,20,21)$ and lung epithelial cell maturation (22-25). Taken together, these studies indicate that EGF can exert effects on both lung morphogenesis and functional maturation of epithelial cells. Inasmuch as TGF- $\alpha$ acts through the same receptor, it might be anticipated that TGF- $\alpha$ would have qualitatively similar effects.

The coimmunolocalization of TGF- $\alpha$ and EGF in developing human lung also suggests that these growth factors may have similar effects in lung development. The simultaneous presence of TGF- $\alpha$ and EGF in fetal lung could explain the inability to inhibit fetal lung growth by the administration of anti-EGF antibody to pregnant mice, despite the elimination of detectible EGF from fetal serum (41). Likewise, normal lung development reported in $\mathrm{TGF}-\alpha$ deficient transgenic mice could be due to the presence of EGF during pulmonary organogenesis $(42,43)$. However, the ability of antisense oligonucleotide directed against EGF to inhibit lung growth in cultured mouse embryo lungs at $11 \mathrm{~d}$ of gestation argues against precisely overlapping functions for TGF- $\alpha$ and EGF in lung morphogenesis (21). It is possible, for example, that local differences in the microenvironment might favor the function of one EGF family member over another.

In lung damaged by HMD the pattern of EGF, TGF- $\alpha$, and EGF-R expression was similar to that seen in fetal lung, except for the expected disruption of distal airway epithelium. Given the potent effects of EGF on developing lung it is possible that the disruption of expression these growth factors in damaged epithelium could contribute to the pathogenesis of abnormal lung growth seen after injury.

The most distinctive histologic feature of lungs from infants with BPD was the abundance of alveolar macrophages that were immunopositive for TGF- $\alpha$, EGF, and EGF-R. This finding is consistent with a previous report of immunolocalization of TGF- $\alpha$ and EGF-R in alveolar macrophages of injured rat lung (27). In addition, it has been shown that human alveolar macrophages produce TGF- $\alpha$, when stimulated with 
endotoxin (44). The association of the EGF family of growth factors with alveolar macrophages suggests that they may be involved with the fibroproliferative changes seen in BPD. Transgenic mice that overexpress the human TGF- $\alpha$ gene under the regulatory control of human surfactant $\mathrm{C}$ promoter develop pulmonary fibrosis with fibrotic lesions localized in peribronchial, peribronchiolar, and perivascular regions (45). The actions of these growth factors in BPD remains uncertain. Their mitogenic (46-48), chemotactic (6-10), and fibrosisstimulating properties, however, could play a significant role in the pathogenesis of abnormal lung growth and fibrosis seen in this disease.

In summary, TGF- $\alpha, \mathrm{EGF}$, and the EGF-R are colocalized in fetal lung from midgestation and in infant lung up to $1 \mathrm{y}$ of age. These growth factors and their receptor are present in airways of both normal and injured developing lung. In lungs from infants who died with BPD prominent immunostaining is seen in alveolar macrophages. These results suggest that the EGF family of growth factors may play a role in normal airway growth, as well as in the abnormal growth and fibrosis seen in BPD.

\section{REFERENCES}

1. Todaro GJ, Fryling C, De Larco JE 1980 Transforming growth factors produced by certain human tumor cells: polypeptides that interact with epidermal growth factor receptors. Proc Natl Acad Sci USA 77:5258-5262

2. Massagué J 1983 Epidermal growth factor-like transforming growth factor. II Interaction with epidermal growth factor receptors in human placenta membranes and A431 cells. J Biol Chem 258:13614-13620

3. Derynck R, Roberts AB, Winkler ME, Chen EY, Goeddel DV 1984 Human transforming growth factor- $\alpha$ : precursor structure and expression in $E$. coli. Cell 38:287297

4. Marquardt H, Hunkapiller MW, Hood LE, Todaro GJ 1984 Rat transforming growth factor type 1: structure and relation to epidermal growth factor. Science 223:10791082

5. Scott-Burden T, Resink TJ, Buhler FR 1988 Growth regulation in smooth muscle cells from normal and hypertensive rats. J Cardiovasc Pharmacol 12(suppl 5):S124S127

6. Nickoloff BJ, Mitra RS, Riser BL, Dixit VM, Varani J 1988 Modulation of keratinocyte motility. Correlation with production of extracellular matrix molecules in response to growth promoting and antiproliferative factors. Am J Pathol 132:543-551

7. Bade EG, Feindler S 1988 Liver epithelial cell migration induced by epidermal growth factor or transforming growth factor- $\alpha$ is associated with changes in the gene expression of secreted proteins. In Vitro Cell Dev Biol 24:149-154

8. Basson MD, Modlin IM, Madri JA 1992 Human enterocyte (Caco-2) migration is modulated in vitro by extracellular matrix composition and epidermal growth factor. $\mathrm{J}$ Clin Invest 90:15-23

9. Schultz G, Chegini N, Grant M, Khaw P, MacKay S 1992 Effects of growth factors on corneal wound healing. Acta Ophthalmol Suppl 70:60-66

10. Mawatari M, Okamura K, Matsuda T, Hamanaka R, Mizoguchi H, Higashio K, Kohno K, Kuwano M 1991 Tumor necrosis factor and epidermal growth factor modulate migration of human microvascular endothelial cells and production of tissue-type plasminogen activator and its inhibitor. Exp Cell Res 192:574-580

11. Adamson ED, Meek J 1984 The ontogeny of epidermal growth factor receptors during mouse development. Dev Biol 103:62-70

12. Sadiq HF, Devaskar UP 1984 Glucocorticoids increase pulmonary epidermal growth factor receptors in female and male fetal rabbit. Biochem Biophys Res Commun 119:408-414

13. Raaberg L, Nexo E, Buckley S, Luo W, Snead ML, Warburton D 1992 Epidermal growth factor transcription, translation, and signal transduction by rat type II pneumocytes in culture. Am J Respir Cell Mol Biol 6:44-49

14. Warburton D, Seth R, Shum L, Horcher PG, Hall FL, Werb Z, Slavkin HC 1992 Epigenetic role of epidermal growth factor expression and signalling in embryonic mouse lung morphogenesis. Dev Biol 149:123-133

15. Stahlman MT, Orth DN, Gray ME 1989 Immunocytochemical localization of epi-

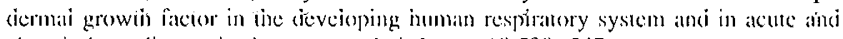
chronic lung discase in the neonate. I ab Invest $(0): 5.30$-.547

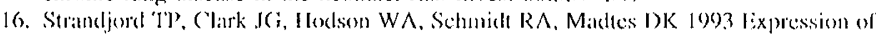
transforming growh folctor-er in mid-gestation human fetal lung. Am J Respir Cell Mol Biol 8:26, 272

17. Brown PI. I am R, I akshmanan I, lïsher I) A I990) Transforming growth factor-er in

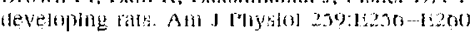

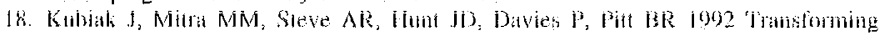

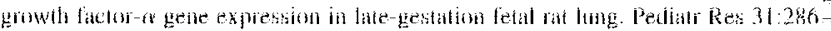
$20(0)$
19. Strandjord TP, Clark JG, Madtes DK 1994 Expression of TGF- $\alpha$, EGF and EGF receptor in fetal rat lung. Am J Physiol 267:L364-L389

20. Goldin GV, Opperman LA 1980 Induction of supernumerary tracheal buds and the stimulation of DNA synthesis in the embryonic chick lung and trachea by epidermal growth factor. J Embryol Exp Morphol 60:235-243

21. Seth R, Shum L, Wu F, Wuenschell C, Hall FL, Slavkin HC, Warburton D 1993 Role of epidermal growth factor expression in early mouse embryo lung branching morphogenesis in culture: antisense oligodeoxynucleotide inhibitory strategy. Dev Biol 158:555-559

22. Gross I, Dynia DW, Rooney SA, Smart DA, Warshaw JB, Sissom JF, Hoath SB 1986 Influence of epidermal growth factor on fetal rat lung development in vitro. Pediatr Res 20:473-477

23. Plopper CG, St.George JA, Read LC, Nishio SJ, Weir AJ, Edwards L, Tarantal AF, Pinkerton KE, Merritt TA, Whitsett JA, George-Nascimento C, Styne D 1992 Acceleration of alveolar type II cell differentiation in fetal rhesus monkey lung by administration of EGF. Am J Physiol 262:L313-L321

24. Catterton WZ, Escobedo MB, Sexson WR, Gray ME, Sundell HW, Stahlman MT 1979 Effect of epidermal growth factor on lung maturation in fetal rabbits. Pediatr Res 13:104-108

25. Sundell HW, Gray ME, Serenius FS, Escobedo MB, Stahlman MT 1980 Effects of epidermal growth factor on lung maturation in fetal lambs. Am J Pathol 100:707-726

26. Vivekananda J, Lin A, Coalson JJ, King RJ 1994 Acute inflammatory injury in the lung precipitated by oxidant stress induces fibroblasts to synthesize and release transforming growth factor- $\alpha$. J Biol Chem 269:25057-25061

27. Madtes DK, Busby HK, Strandjord TP, Clark JG 1994 Expression of transforming growth factor- $\alpha$ and epidermal growth factor receptor is increased following bleomycin-induced lung injury in rats. Am J Respir Cell Mol Biol 11:540-551

28. Mercer BM, Sklar S, Shariatmadar A, Gillieson MS, D'Alton ME 1987 Fetal foot length as a predictor of gestational age. Am J Obstet Gynecol 156:350-355

29. Northway WH, Rosan RC, Porter DY 1967 Pulmonary disease following respirator therapy of hyaline-membrane disease. N Engl J Med 276:357-368

30. Sorvillo JM, McCormack ES, Yanez L, Valenzuela D, Reynolds Jr F 1990 Preparation and characterization of monoclonal antibodies specific for human transforming growth factor- $\alpha$. Oncogene 5:377-386

31. Samuels V, Barrett JM, Bockman S, Pantazis CG, Allen Jr M 1989 Immunocytochemical study of transforming growth factor expression in benign and malignant gliomas. Am J Pathol 134:894-902

32. Gullick WJ, Downward J, Parker PJ, Whittle N, Kris R, Schlessinger J, Ullrich A, Waterfield MD 1985 The structure and function of the epidermal growth factor receptor studied by using antisynthetic peptide antibodies. Proc R Soc Lond B Biol Sci 226:127-134

33. Woodcock -Mitchell J, Eichner R, Nelson WG, Sun TT 1982 Immunolocalization of keratin polypeptides in human epidermis using monoclonal antibodies. $\mathrm{J}$ Cell Biol 95:580-588

34. Gown AM, Tsukada T, Ross R 1986 Human atherosclerosis. II. Immunocytochemical analysis of the cellular composition of human atherosclerotic lesions. Am J Pathol 125:191-207

35. Hsu S, Raine L, Fanger H 1981 A comparative study of the peroxidase-antiperoxidase method and an avidin-biotin complex method for studying polypeptide hormones with radioimmunoassay antibodies. J Clin Pathol 75:734-738

36. Gown AM, Vogel AM 1984 Monoclonal antibodies to human intermediate filament proteins. II. Distribution of filament proteins in normal human tissues. Am J Pathol 114:309-311

37. Snead ML, Luo W, Oliver P, Nakamura M, Wheeler DG, Bessem C, Bell GI, Rall LB, Slavkin HC 1989 Localization of epidermal growth factor precursor in tooth and lung during embryonic mouse development. Dev Biol 134:420-429

38. Sannes PL, Burch KK, Khosla J 1992 Immunohistochemical localization of epidermal growth factor and acidic and basic fibroblast growth factors in postnatal developing and adult rat lungs. Am J Respir Cell Mol Biol 7:230-237

39. Raaberg L, Poulsen SS, Nexo E 1991 Epidermal growth factor in the rat lung. Histochemistry 95:471-475

40. Johnson MD, Gray ME, Carpenter G, Pepinsky RB, Stahlman MT 1990 Ontogeny of epidermal growth factor receptor and lipocortin-1 in fetal and neonatal human lungs. Hum Pathol 21:182-191

41. Yasui S, Nagai A, Oohira A, Iwashita M, Konno K 1993 Effects of anti-mouse EGF antiserum on prenatal lung development in fetal mice. Pediatr Pulmonol 15:251-256

42. Mann GB, Fowler KJ, Gabriel A, Nice EC, Williams RL, Dunn AR 1993 Mice with a null mutation of the TGF- $\alpha$ gene have abnormal skin architecture, wavy hair, and curly whiskers and often develop corneal inflammation. Cell 73:249-261

43. Luetteke NC, Qiu TH, Peiffer RL, Oliver P, Smithies O, Lee DC 1993 TGF- $\alpha$ deficiency results in hair follicle and eye abnormalities in targeted and waved-1 mice. Cell 73:263-278

44. Madtes DK, Raines EW, Sakariassen KS, Assoian RK, Sporn MB, Bell GI, Ross R 1988 Induction of transforming growth factor- $\alpha$ in activated human alveolar macropharen. Cell 52:285, 203,

45. Korthagen ITR, Swantz. RJ, Wert Sl; McCarty JM, Kerlakian ('B, Cilasser SW, Whitsell is 19O4 Respiratory epithelial cell expression of human transforming

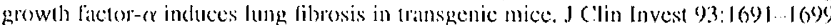

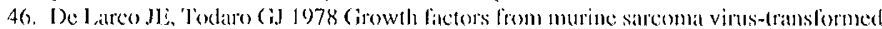
cells. Proc Natl Acad Sci USA 75:400)1 - 400)5

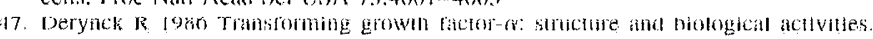
j Cell isochem 32:303 -304

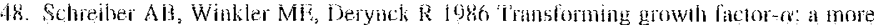
potent angiogenic thediator than epidemal growth factor. Seience 232:1250-1253 